\title{
Climate change impacts on sugarcane attainable yield in southern Brazil
}

\author{
Fabio R. Marin • James W. Jones • Abraham Singels • \\ Frederick Royce • Eduardo D. Assad • \\ Giampaolo Q. Pellegrino• Flávio Justino
}

Received: 7 December 2010 / Accepted: 28 July 2012 / Published online: 25 August 2012

C The Author(s) 2012. This article is published with open access at Springerlink.com

\begin{abstract}
This study evaluated the effects of climate change on sugarcane yield, water use efficiency, and irrigation needs in southern Brazil, based on downscaled outputs of two general circulation models (PRECIS and CSIRO) and a sugarcane growth model. For three harvest cycles every year, the DSSAT/CANEGRO model was used to simulate the baseline and four future climate scenarios for stalk yield for the 2050s. The model was calibrated for the main cultivar currently grown in Brazil based on five field experiments under several soil and climate conditions. The sensitivity of simulated stalk fresh mass (SFM) to air temperature, $\mathrm{CO}_{2}$ concentration $\left[\mathrm{CO}_{2}\right]$ and rainfall was also analyzed. Simulated SFM responses to $\left[\mathrm{CO}_{2}\right]$, air temperature and rainfall variations were consistent with the literature. There were increases in simulated SFM and water usage efficiency (WUE) for all scenarios. On average,
\end{abstract}

F. R. Marin $(\bowtie) \cdot$ E. D. Assad • G. Q. Pellegrino

Embrapa Agricultural Informatics, Av. André Tosello, 209 - Barão Geraldo, CP 6041- 13083-886 Campinas, SP, Brazil

e-mail: marin@cnptia.embrapa.br

E. D. Assad

e-mail: assad@cnptia.embrapa.br

G. Q. Pellegrino

e-mail: giam@cnptia.embrapa.br

J. W. Jones · F. Royce

Department of Agricultural and Biological Engineering, University of Florida, PO Box 110570,

Gainesville, FL, USA

J. W. Jones

e-mail: jimj@ufl.edu

F. Royce

e-mail: froyce@ufl.edu

A. Singels

South African Sugarcane Research Institute, Private Bag X02, Mount Edgecombe 4300, South Africa e-mail: abraham.singels@sugar.org.za

F. Justino

Departamento de Engenharia Agricola, Universidade Federal de Viçosa, 36570-000 Viçosa, MG, Brazil e-mail: fjustino@ufv.br 
for the current sugarcane area in the State of São Paulo, SFM would increase $24 \%$ and WUE $34 \%$ for rainfed sugarcane. The WUE rise is relevant because of the current concern about water supply in southern Brazil. Considering the current technological improvement rate, projected yields for 2050 ranged from 96 to 129 tha $^{-1}$, which are respectively 15 and $59 \%$ higher than the current state average yield.

\section{Introduction}

Global climate variability and change caused by natural processes and anthropogenic factors may result in major environmental issues that will affect the world during the 21 st century. Recent estimates of temperature increases from the IPCC Fourth Assessment Report (AR4) are in the range $1.8-4{ }^{\circ} \mathrm{C}$ in $2090-2099$ relative to $1980-1999$, and climate variability and change are projected to result in changes in the frequency of extreme high-temperature events, floods and droughts (Trenberth et al. 2007). In Brazil, observations show a tendency for an increase in the frequency of extreme rainfall events in southern Brazil (Groissman et al. 2005), while projections show tendencies for increasing extremes in both maximum and minimum temperatures, and high spatial variability for rainfall under the A2 and B2 scenarios (Marengo et al. 2009).

The challenges faced by the agricultural sector under the climate change scenarios are to provide food security for an increasing world population while protecting the environment and the functioning of its ecosystems (Rosenzweig et al. 2012). For countries that are highly dependent on natural resources, these challenges may be amplified by extreme events having social and economic impacts that far outweigh their apparent probabilities of occurrence (Thornton et al. 2009). The impacts on agriculture have special importance for Brazil, since nearly $30 \%$ of Brazilian gross national product is related to agribusiness (Barros 2009).

Sugarcane is one of the world's major food-producing C4 crops, providing about $75 \%$ of sugar produced in the world for human consumption (Souza et al. 2008). Brazil is the world's largest sugarcane producer, and the State of São Paulo produces nearly $60 \%$ of Brazilian sugarcane under rainfed conditions. This high dependence on rainfed production highlights the importance of the weather on sugarcane production, and hence on the sugar, ethanol and electricity markets at regional, national, and global scales.

The adaptation of farming systems to climate change demands to take advantage of the potential benefits and minimize potential adverse impacts to crop production. Knox et al. (2010) and Biggs et al. (2012) used crop models to assess sugarcane responses to future climate scenarios, but no such study has been done for Brazil until now. In this paper, we simulated the impacts of climate change on sugarcane in southern Brazil using the DSSAT/ CANEGRO model and a range of four projected downscaled climate scenarios, to estimate the likely future impacts on the crop in terms of cane yield and water use efficiency.

\section{Material and methods}

\subsection{Modeling sugarcane yield}

\subsubsection{The DSSAT/CANEGRO model}

The DSSAT/CANEGRO model (Singels et al. 2008) was shown to satisfactorily predict Brazilian sugarcane in southern Brazil (Marin et al. 2011; Nassif et al. 2012). The algorithm 
for photosynthesis in DSSAT/CANEGRO (version 4.5.0.047) calculates daily increments of total biomass using a radiation use efficiency approach (Singels and Bezuidenhout 2002) and a $\mathrm{CO}_{2}$ concentration $\left[\mathrm{CO}_{2}\right]$ fertilization effect algorithm (A. Singels and M. Jones, South African Sugarcane Research Institute, personal communication, 2011) which together account for the photosynthesis $\left(\mathrm{P}_{\mathrm{G}}\right)$ and hence yield (Eq. 1):

$$
P_{\mathrm{G}}=F i \cdot \mathrm{PAR} \cdot \mathrm{RUE} \cdot R_{\mathrm{PG}}
$$

where PAR is photosynthetically-active solar radiation $\left(\mathrm{MJ} \mathrm{m}^{-2}\right)$, RUE is radiation use efficiency (g.M J ${ }^{-1}$ ) and $\mathrm{Fi}$ is fractional interception of PAR. The standard $\mathrm{P}_{\mathrm{G}}$ at a $\left[\mathrm{CO}_{2}\right]$ of $330 \mathrm{ppm}$ is adjusted using an adjustment factor $\left(\mathrm{R}_{\mathrm{PG}}\right)$ that depends on $\left[\mathrm{CO}_{2}\right]$. Rather than defining this relationship mathematically, DSSAT provides a mechanism for interpolating $\mathrm{R}_{\mathrm{GP}}$ from a set of coordinate pairs (G. Hoogenboom, Washington State University, personal communication, 2011). Each of these data points are defined in the species file. The function for maize (taken from the 2011 DSSAT version 4.5.0.047 source code) was used for sugarcane.

Besides the effect on photosynthesis DSSAT/CANEGRO also simulates the impact of $\left[\mathrm{CO}_{2}\right]$ on stomatal resistance and transpiration (Long et al. 2004) following the method proposed by Allen et al. (1985). Although derived for sweet corn, the method compared well with sugarcane stomatal diffusion resistances measured under ambient atmospheric $\left[\mathrm{CO}_{2}\right]$ by Venkataramana et al. (1986), Grantz and Meinzer (1990), Souza et al. (2008), and Vu and Allen (2009).

DSSAT uses an adjustment factor for potential transpiration. This factor is derived from the theoretical ratio of grass reference evapotranspiration calculated using the PenmanMonteith equation with canopy resistance calculated for the relevant $\left[\mathrm{CO}_{2}\right]$ to that calculated using the reference $\left[\mathrm{CO}_{2}\right]$ of $330 \mu \mathrm{mol} \mathrm{mol}^{-1}$. This, in turn, was derived from the fact that $\mathrm{C} 4$ plants have a $\mathrm{CO}_{2}$ concentrating mechanism in the leaf mesophyll cells which binds $\mathrm{CO}_{2}$ and transports it as a four-carbon molecule to vascular bundle sheath cells for decarboxilation (Allen et al. 1985).

\subsubsection{Model calibration}

Crop simulations were based on the cultivar RB86-7515, which occupied $28 \%$ of the sugarcane area in Brazil during the 2010/2011 season. Calibration of the model to this cultivar was done using the field data obtained in five locations around Brazil under distinct soil and climate conditions (Table 1).

Field data mainly consisted of stalk fresh mass (SFM), number of green leaves, tiller population and leaf area index (LAI). The calibration was made by eye-fitting while minimizing the RMSE for SFM and LAI. Statistical results for SFM were RMSE $=9.2 \mathrm{t}$ $\mathrm{ha}^{-1}, R^{2}=0.97$ and for LAI they were $\mathrm{RMSE}=1.02 \mathrm{tha}^{-1}$ and $R^{2}=0.36$. All experiments received adequate $\mathrm{N}, \mathrm{P}$ and $\mathrm{K}$ fertilization and regular weed control and were planted using healthy cuttings with 13 to 15 buds $\mathrm{m}^{-2}$. Row spacing varied from 1.4 to $1.5 \mathrm{~m}$. One of the datasets had three irrigation levels: irrigated, partial irrigation (20\% of ETo) and rainfed, while all the remaining data were from rainfed conditions.

\subsubsection{Crop model settings for simulating climate change scenarios}

All simulations were done for rainfed cropping conditions, as irrigation is not generally used for sugarcane in the region. This simulates a typical southern Brazil ratoon crop, with a 12-month 


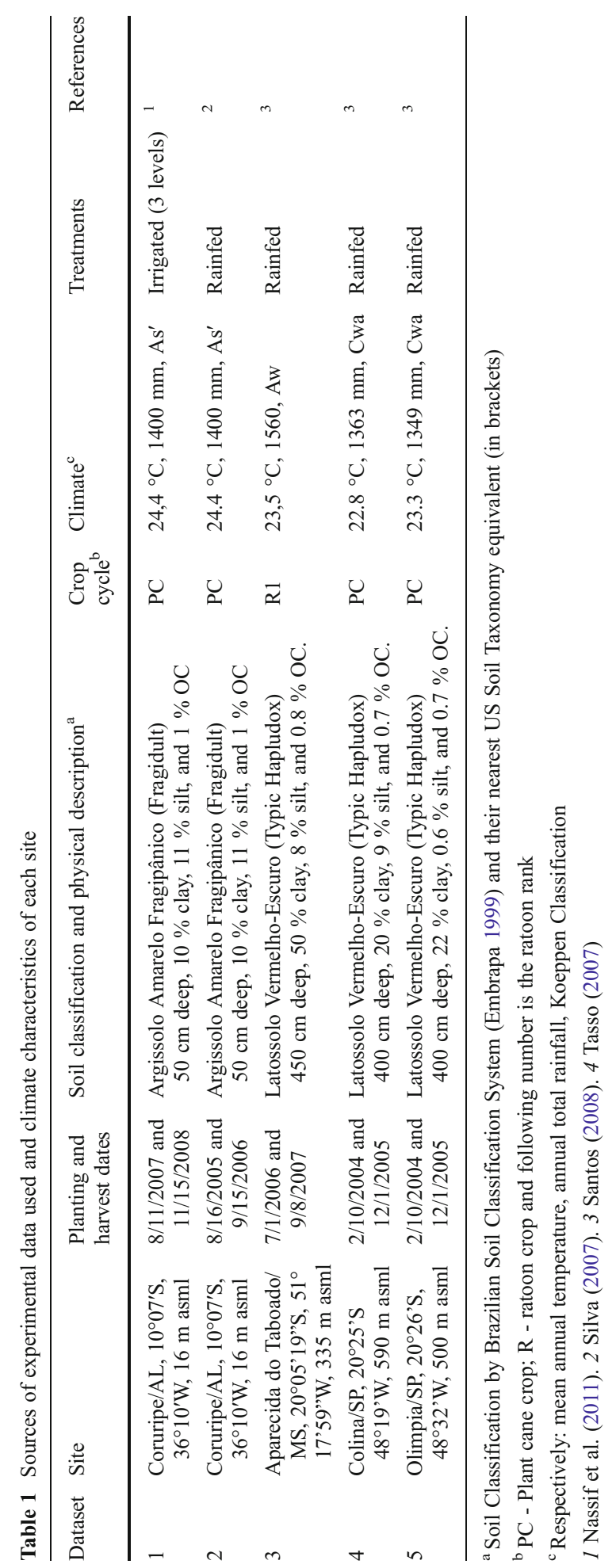


cycle, in which the harvest of a previous crop also initiates the new growth period. We assumed that $28 \%$ of total ratoon area was planted on May 15th (early season); $44 \%$ on August 15th (medium season); and $28 \%$ on November 15 th (late season), representing the three main cycles of ratoon crops. Harvest season usually goes from May to November.

The baseline dataset had 79 weather stations distributed over the State of São Paulo and portions of neighboring States. These locations were selected to have at least 8 years of continuous daily weather measurements within the 15 growing seasons period 1992-2007.

For 75 stations, daily solar radiation values were estimated using the Bristow and Campbell (1984) method previously calibrated using $A=0.7812, B=0.00515$, and $C=2.2$ as model parameters. A previous evaluation using 2,245 daily data from four weather stations in the State of São Paulo showed the model underestimating observed daily solar radiation by $1 \%\left(R^{2}=0.64\right)$.

The soils of the State of São Paulo were grouped into the three major classes (Oliveira et al. 1999) (Table 2). The soil depth was set in order to represent the root depth in commercial ratoon fields based on Korndörfer et al. (1989), Barbieri et al. (1997), and Alvarez et al. $(2000 \mathrm{a}, \mathrm{b})$. The soils input data of the locations of neighboring States were assessed through soil maps provided by the Radambrasil Project (1973-1986). We follow the procedures described in Marin et al. (2011) to create soil data files in the DSSAT format.

\subsection{Model sensitivity to air temperature, $\mathrm{CO}_{2}$ concentration and rainfall}

The DSSAT/CANEGRO model sensitivities to weather variables - $\mathrm{CO}_{2}$, rainfall and air temperature - were evaluated. The following scenarios were simulated for air temperature: $-3{ }^{\circ} \mathrm{C},+3{ }^{\circ} \mathrm{C},+6{ }^{\circ} \mathrm{C}$ and $9{ }^{\circ} \mathrm{C}$; for rainfall: -30 and $+30 \%$; and $\left(\mathrm{CO}_{2}\right)$ levels of 350,450 , $550,650,750$, and $850 \mathrm{ppm}$. Piracicaba (mean annual temperature $21.6{ }^{\circ} \mathrm{C}$ and annual rainfall of $1,230 \mathrm{~mm}$ ) and Ilha Solteira (mean annual temperature $25.6{ }^{\circ} \mathrm{C}$ and annual rainfall of $1,156 \mathrm{~mm}$ ), where observed rainfall, solar radiation and air temperature from 1992 to 2007 were chosen as representative of different regions of the State of São Paulo. The

Table 2 Soil properties input for DSSAT/CANEGRO model for each calibration dataset

\begin{tabular}{|c|c|c|c|c|c|c|c|c|c|}
\hline $\begin{array}{l}\text { Layer } \\
\text { depth } \\
\mathrm{cm}\end{array}$ & $\begin{array}{l}\text { Lower } \\
\text { limit, } \\
\mathrm{cm}^{3} \mathrm{~cm}^{-3}\end{array}$ & $\begin{array}{l}\text { Upper limit } \\
\text { drain., } \mathrm{cm}^{3} \\
\mathrm{~cm}^{-3}\end{array}$ & $\begin{array}{l}\text { Upper limit } \\
\text { sat., } \\
\mathrm{cm} \mathrm{cm}^{-3}\end{array}$ & $\begin{array}{l}\text { Root } \\
\text { growth } \\
\text { factor }\end{array}$ & $\begin{array}{l}\text { Sat. hyd. } \\
\text { cond., } \\
\mathrm{cm} \mathrm{h}^{-1}\end{array}$ & $\begin{array}{l}\text { Bulk } \\
\text { density, } \\
\mathrm{g} \mathrm{cm}^{-3}\end{array}$ & $\begin{array}{l}\text { Organic } \\
\text { carbon, } \%\end{array}$ & Clay, \% & Silt, $\%$ \\
\hline \multicolumn{10}{|c|}{ Soil 1 - high suitability } \\
\hline 25 & 0.20 & 0.31 & 0.48 & 0.81 & 0.28 & 1.37 & 0.9 & 54 & 17 \\
\hline 70 & 0.23 & 0.33 & 0.48 & 0.55 & 0.31 & 1.35 & 0.8 & 66 & 8 \\
\hline 85 & 0.24 & 0.34 & 0.49 & 0.31 & 0.28 & 1.13 & 0.5 & 64 & 8 \\
\hline 135 & 0.25 & 0.35 & 0.49 & 0.22 & 0.30 & 1.13 & 0.1 & 64 & 10 \\
\hline \multicolumn{10}{|c|}{ Soil 2 - medium suitability } \\
\hline 10 & 0.11 & 0.16 & 0.44 & 0.97 & 0.72 & 1.17 & 1.4 & 30 & 38 \\
\hline 25 & 0.11 & 0.16 & 0.44 & 0.80 & 0.73 & 1.39 & 0.7 & 36 & 37 \\
\hline 85 & 0.14 & 0.25 & 0.45 & 0.55 & 0.55 & 1.39 & 0.3 & 57 & 30 \\
\hline 105 & 0.16 & 0.26 & 0.45 & 0.31 & 0.50 & 1.44 & 0.1 & 36 & 48 \\
\hline \multicolumn{10}{|c|}{ Soil 3 - low suitability } \\
\hline 15 & 0.09 & 0.21 & 0.50 & 0.91 & 0.65 & 1.08 & 2.38 & 28 & 15 \\
\hline 35 & 0.10 & 0.27 & 0.47 & 0.27 & 0.49 & 1.16 & 1.00 & 35 & 17 \\
\hline 55 & 0.16 & 0.27 & 0.46 & 0.10 & 0.44 & 1.46 & 0.56 & 6 & 16 \\
\hline
\end{tabular}


sensitivities were studied by simulating environmental modifications for 15 years and analyzing mean and standard deviation responses.

\subsection{Climate change scenarios and datasets}

One of the climate scenarios utilized here (PRECIS) was downscaled with the HadRM3P Regional Climate Model from the UK Met Office for present day (1961-1990) and future (2010-2100) conditions using experiments conducted with horizontal resolution of $50 \mathrm{~km}$ as described by Marengo et al. (2009) and Alves and Marengo (2010).

To increase the range of future projections this study also applies additional daily outputs of another global circulation model, namely CSIRO (Gordon et al. 2002), also for both the A2 and B2 scenarios. The results presented have been interpolated to a $0.5 \times 0.5$ degree grid by applying OACRES (Objective Analysis using the Cressman scheme (Cressman 1959) following the approach used by Justino et al. (2011).

The future projections used herein are commonly referred to as A2 (economic-regional) and $\mathrm{B} 2$ (environmental-regional). $\left[\mathrm{CO}_{2}\right]$ was fixed at $720 \mathrm{ppm}$ for the $\mathrm{A} 2$ scenario and at $500 \mathrm{ppm}$ for the B2 (Arnell 2004). These values were close to conditions under which sugarcane has been tested for $\mathrm{CO}_{2}$ effects ( $\mathrm{Vu}$ and Allen 2009; Souza et al. 2008). The baseline was simulated using $\left[\mathrm{CO}_{2}\right]=380 \mathrm{ppm}$.

The delta method (Gleick 1986) was used to create four additional climate scenarios in addition to the baseline, for each of 79 sites throughout the State of São Paulo. This was achieved through a weather station specific change-factor for monthly maximum and minimum temperature and rainfall, which was applied to the historical baseline to change the daily observed values. The data of each scenario were spatially organized and the maps were generated by kriging interpolation for the sugarcane grown area in the State of São Paulo during the 2007-2008 growing season.

\section{Results and discussion}

3.1 Model sensitivity to air temperature, rainfall and $\mathrm{CO}_{2}$

The stalk fresh mass (SFM) responded positively to an increase in air temperature (Fig. 1a) for Piracicaba up to $+6{ }^{\circ} \mathrm{C}$ (11\% higher than the baseline), decreasing thereafter. For Ilha Solteira, the SFM response was flatter $\left(3 \%\right.$ higher than the baseline at $\left.+3{ }^{\circ} \mathrm{C}\right)$, and negative ( $5 \%$ lower than the baseline) for an increase of $+9{ }^{\circ} \mathrm{C}$.

Rates of photosynthesis, respiration, expansive growth and evapotranspiration are influenced by air temperature in the DSSAT/CANEGRO. Increased temperatures caused large increase in potential evapotranspiration (7.8 and $10.5 \%$ increase at Piracicaba and Ilha Solteira respectively for $+3{ }^{\circ} \mathrm{C}$ rise) and accelerated canopy development ( $80 \%$ canopy cover reached 15 days sooner for $+3{ }^{\circ} \mathrm{C}$ at both sites. This led to an increase in canopy photosynthesis and actual crop evapotranspiration 6.6 and $6.1 \%$ at Piracicaba and Ilha Solteira for $+3{ }^{\circ} \mathrm{C}$ due to increased interception of radiation. The increased evapotranspiration led to an increase in severity of water stress. In the DSSAT/CANEGRO model water stress is quantified using a soil water deficit factor (SWDF1, see Singels et al. 2008) that ranges from 1 (no stress) to zero (fully stressed). For Piracicaba, the average SWDF1 value increased by 6.7 and $26.7 \%$ for the $+3{ }^{\circ} \mathrm{C}$ and $+6{ }^{\circ} \mathrm{C}$ scenarios. For Ilha Solteira, the corresponding responses were 3.7 and $11.1 \%$ respectively. The reason for the lower response at Ilha Solteira compared to Piracicaba, is because the water stress levels of the 


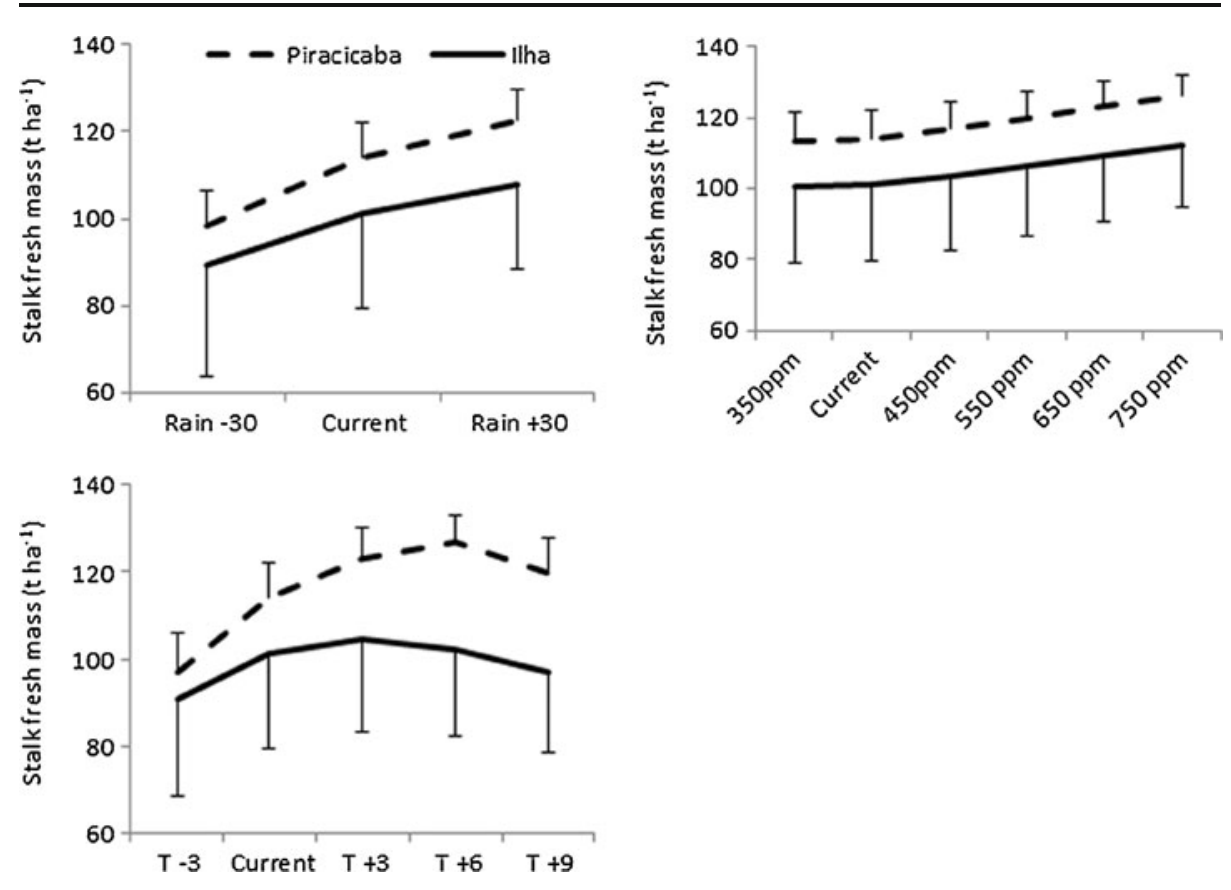

Fig. 1 DSSAT/CANEGRO model sensitivity to several levels of $\mathrm{CO}_{2}$ concentration, air temperature and rainfall, compared to base line (BL), for two locations of the State of São Paulo

baseline scenario are much higher at Ilha Solteira than at Piracicaba during the rainy season. Both locations have a dry period during the winter, but it is notably drier in Ilha Solteira than Piracicaba.

The response of stalk fresh mass (SFM) to $\left[\mathrm{CO}_{2}\right]$ observed in Fig. $1 \mathrm{~b}$ is a consequence of elevated $\left[\mathrm{CO}_{2}\right]$ effects on transpiration and photosynthesis rate in DSSAT/CANEGRO. The effect on transpiration response is due to the mechanism leading $\mathrm{C} 4$ plants to partially close their stomata and increase stomatal resistance and leaf transpiration under elevated $\left[\mathrm{CO}_{2}\right]$. The lower stomatal conductance reduces sap flow and increases xylem potential, leading to an improved plant water status (Owensby et al. 1997). The responses of different C4 species vary, but a survey from Drake et al. (1997) for 41 observations covering 28 species suggests an average decrease in stomatal conductance of nearly $20 \%$. Yet, because of these anatomical and physiological characteristics, $\mathrm{C} 4$ plants are assumed to respond to higher $\left[\mathrm{CO}_{2}\right]$ by closing their stomata to a greater extent than $\mathrm{C} 3$ plants as $\left[\mathrm{CO}_{2}\right]$ is increased (Tolbert and Zelitch 1983).

Data in Fig. 1b shows a direct relationship between SFM and $\left[\mathrm{CO}_{2}\right]$ for Piracicaba and Ilha Solteira, despite the climate differences for the sites. The lower yield for Ilha Solteira is because of the drier climate and higher water deficits compared to Piracicaba. Interestingly, under high $\left[\mathrm{CO}_{2}\right]$ in both locations there was a decrease in the variability of SFM, as shown by the errors bars in Fig. 1.

In the model, increased $\left[\mathrm{CO}_{2}\right]$ caused a large reduction in crop transpiration $(-11.0$ and $-10.5 \%$ for Piracicaba and Ilha Solteira respectively at $750 \mathrm{ppm}$ ) and hence evapotranspiration $(-9.1$ and $-8.9 \%$ at $750 \mathrm{ppm})$. This caused a large reduction in water stress severity $(-46.7$ and $-22.2 \%$ at $750 \mathrm{ppm})$, resulting in increases in SFM of 10.4 and $10.8 \%$ at $750 \mathrm{ppm}$ at Piracicaba and Ilha Solteira respectively. 
Until recently, $\mathrm{C} 4$ plants were thought not to respond to the increase in $\left[\mathrm{CO}_{2}\right]$ based on the results found by authors such as Ottman et al. (2001) for sorghum, Leakey et al. (2006) for maize and Maherali et al. 2002 for a Texas native C4 grassland. This seems do not reflect the last studies on sugarcane growth under modified environments as reported by Ziska and Bunce (1997), Vu et al. (2006), Souza et al. (2008), and Vu and Allen (2009).

For both locations, SFM showed a positive response to rainfall increase $(+7.4$ and $6.4 \%$ at Piracicaba and Ilha Solteira respectively). The rainfall range of $60 \%$ led to increases in SFM of 21.2 and $18.2 \%$ at Piracicaba and Ilha Solteira respectively (Fig. 1c), and the temporal yield variability was reduced as rainfall was increased at Ilha Solteira, as indicated by the $\mathrm{CV} \%$ reduction from 24.5 to $18.7 \%$.

\subsection{Climate change impacts on sugarcane production}

\subsubsection{Stalk fresh mass}

There were no sugarcane yield losses in southern Brazil for none of the climate projections analyzed, with gains ranging from $1 \%$ for PRECIS B2-Late cycle to $54 \%$ PRECIS A2-early cycle (Table 3 ). Major yield gains were observed for the early cycle, followed by the gains for medium and late cycle respectively for all climate projections. This confirmed to expectations, since early harvested areas usually have higher yield than medium or late ones. For the most commonly used cultivar in southern Brazil, sucrose concentration follows a distinct trend, as medium cycles crops show higher sucrose concentration than early and late cycles. Assuming the same tendency, we would expect an important increase in sucrose production mainly for the medium cycles. Simulating climate change impacts for irrigated sugarcane production in Swaziland, Knox et al. (2010) found a decreasing trend for future projections for SFM unless irrigation was included in the simulations.

Table 3 Average and standard deviation for stalk fresh mass $\left(\mathrm{t} \mathrm{ha}^{-1}\right)$ and water use efficiency-WUE, $\mathrm{kg}$ $\left(\right.$ Stalk DM) $\mathrm{m}^{-3}$ (ET) - for each climate scenario and the percentage change compared to the baseline

\begin{tabular}{|c|c|c|c|c|c|c|}
\hline \multirow{2}{*}{$\begin{array}{l}\text { Harvest Time } \\
\text { Early }\end{array}$} & \multirow[t]{2}{*}{ Model } & \multirow{2}{*}{$\begin{array}{c}\text { Scenario } \\
\text { Baseline }\end{array}$} & \multicolumn{2}{|c|}{ WUE $\left(\mathrm{kg} \mathrm{m}^{-3}\right)$} & \multicolumn{2}{|c|}{ Stalk fresh mass $\left(\mathrm{t} \mathrm{ha}^{-1}\right)$} \\
\hline & & & $4.20 \pm 0.90$ & $0 \%$ & $73.1 \pm 32.6$ & $0 \%$ \\
\hline & CSIRO & A2 & $6.01 \pm 0.75$ & $43 \%$ & $91.7 \pm 30.1$ & $26 \%$ \\
\hline & & $\mathrm{B} 2$ & $4.84 \pm 0.87$ & $15 \%$ & $79.3 \pm 32.3$ & $8 \%$ \\
\hline & PRECIS & $\mathrm{A} 2$ & $6.64 \pm 0.50$ & $58 \%$ & $112 . \pm 21.6$ & $54 \%$ \\
\hline & & $\mathrm{B} 2$ & $5.52 \pm 0.69$ & $32 \%$ & $91.2 \pm 24.2$ & $25 \%$ \\
\hline \multirow[t]{5}{*}{ Medium } & & Baseline & $3.98 \pm 0.71$ & $0 \%$ & $66.8 \pm 24.4$ & $0 \%$ \\
\hline & CSIRO & A2 & $5.68 \pm 0.57$ & $43 \%$ & $82.4 \pm 22.7$ & $23 \%$ \\
\hline & & B2 & $4.57 \pm 0.68$ & $15 \%$ & $71.8 \pm 24.2$ & $7 \%$ \\
\hline & PRECIS & A2 & $6.31 \pm 0.51$ & $58 \%$ & $99.5 \pm 19.8$ & $49 \%$ \\
\hline & & B2 & $5.24 \pm 0.62$ & $32 \%$ & $81.5 \pm 22.1$ & $22 \%$ \\
\hline \multirow[t]{5}{*}{ Late } & & Baseline & $4.40 \pm 0.64$ & $0 \%$ & $70.3 \pm 20.5$ & $0 \%$ \\
\hline & CSIRO & A2 & $6.12 \pm 0.55$ & $39 \%$ & $84.7 \pm 17.4$ & $20 \%$ \\
\hline & & B2 & $5.01 \pm 0.60$ & $14 \%$ & $75.4 \pm 20.2$ & $7 \%$ \\
\hline & PRECIS & $\mathrm{A} 2$ & $6.23 \pm 0.59$ & $41 \%$ & $86.9 \pm 17.9$ & $24 \%$ \\
\hline & & B2 & $5.10 \pm 0.66$ & $16 \%$ & $71.2 \pm 18.8$ & $1 \%$ \\
\hline Weighted average & & & & $34 \%$ & & $22 \%$ \\
\hline
\end{tabular}


Weighted averages for SFM were $22 \%$ higher than the baseline (Table 3). Simulations using CSIRO climate projections resulted in averaged an increase of $15 \%$ compared to baseline, while PRECIS climate projections resulted in an SFM increase of $29 \%$. Interestingly, CSIRO projected rainfall increasing by about $70 \%$, mainly during the dry period of year, and very little changes in temperatures for A2 and B2 scenarios. PRECIS projection, on the other hand, represents an increase in temperature around $2{ }^{\circ} \mathrm{C}$ and reduction of rainfall by $25 \%$. CSIRO projections also include a slight decrease in solar radiation while in the PRECIS scenarios solar radiation increased. These distinct climate projections are reflected in the sugarcane yield, because the pathways to the yield outcomes were different for each climate projection. For the CSIRO, the yield increase occurred mostly because of the higher rainfall. The PRECIS model, in turn, produced higher yields because of the positive effects of higher temperature, in addition to the elevated $\left[\mathrm{CO}_{2}\right]$.

In general, for the range of the climate projections analyzed here we could conclude that the benefit of increasing temperature and $\left[\mathrm{CO}_{2}\right]$ overrides the disadvantage of reducing rainfall (as projected by PRECIS) for sugarcane crops in southern Brazil. Based on this, we could infer the sugarcane may also be limited by $\mathrm{CO}_{2}$, temperature and solar radiation, besides rainfall.

Besides the increase of SFM, future climate projections would also decrease the SFM temporal variability (Fig. 2) for the three harvest dates, which would correspond to a reduction in the production risks for sugarcane, mainly for the PRECIS projections in early and medium cycles (Fig. 2a, b). The lower probability of low yields in future climates represents a major favorable impact for Brazil as whole. Recently, oscillations in sugarcane yield due to weather and management have had large social and economic impacts.

Maps of SFM variation (Fig. 3) shows the major SFM increases for the central-north region of the State of São Paulo, which exhibits soils with high water-holding capacity, adequate temperatures, and high amounts of rainfall and solar radiation. Under a temperature-increase scenario, the southern State of São Paulo may become more appropriate for sugarcane production in the future. On the other hand, it is reasonable to argue that western and northwestern regions of São Paulo would be the areas most favorably affected by climate change (Fig. 3), due to current water and temperature stresses on the sugarcane, which should be alleviated by the effect of $\mathrm{CO}_{2}$ fertilization on the sugarcane photosynthesis and yield.

Despite the simulations uncertainties (see Uncertainties and limitations), assuming the same technological improvement rate regarding crop management and genetic breeding as has occurred in the last 20 years $(+0.67 \%$ SFM gain per year) we can expect SFM yields for 2050 ranging from 96 to 129 tha $^{-1}$, considering the best (HasCM3 A2) and the worst
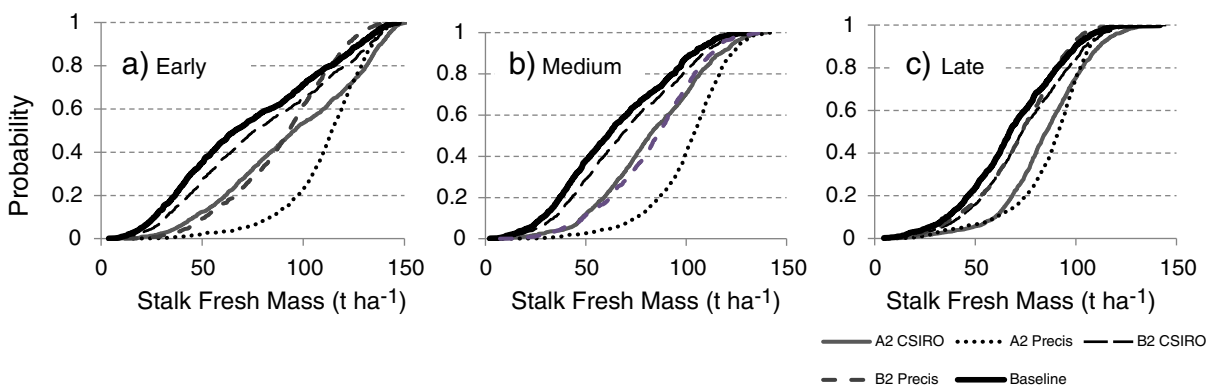

Fig. 2 Cumulative probability of stalk fresh mass (SFM) for the baseline and four projected climates for 2050, for three sugarcane harvest dates commonly used in the State of São Paulo 

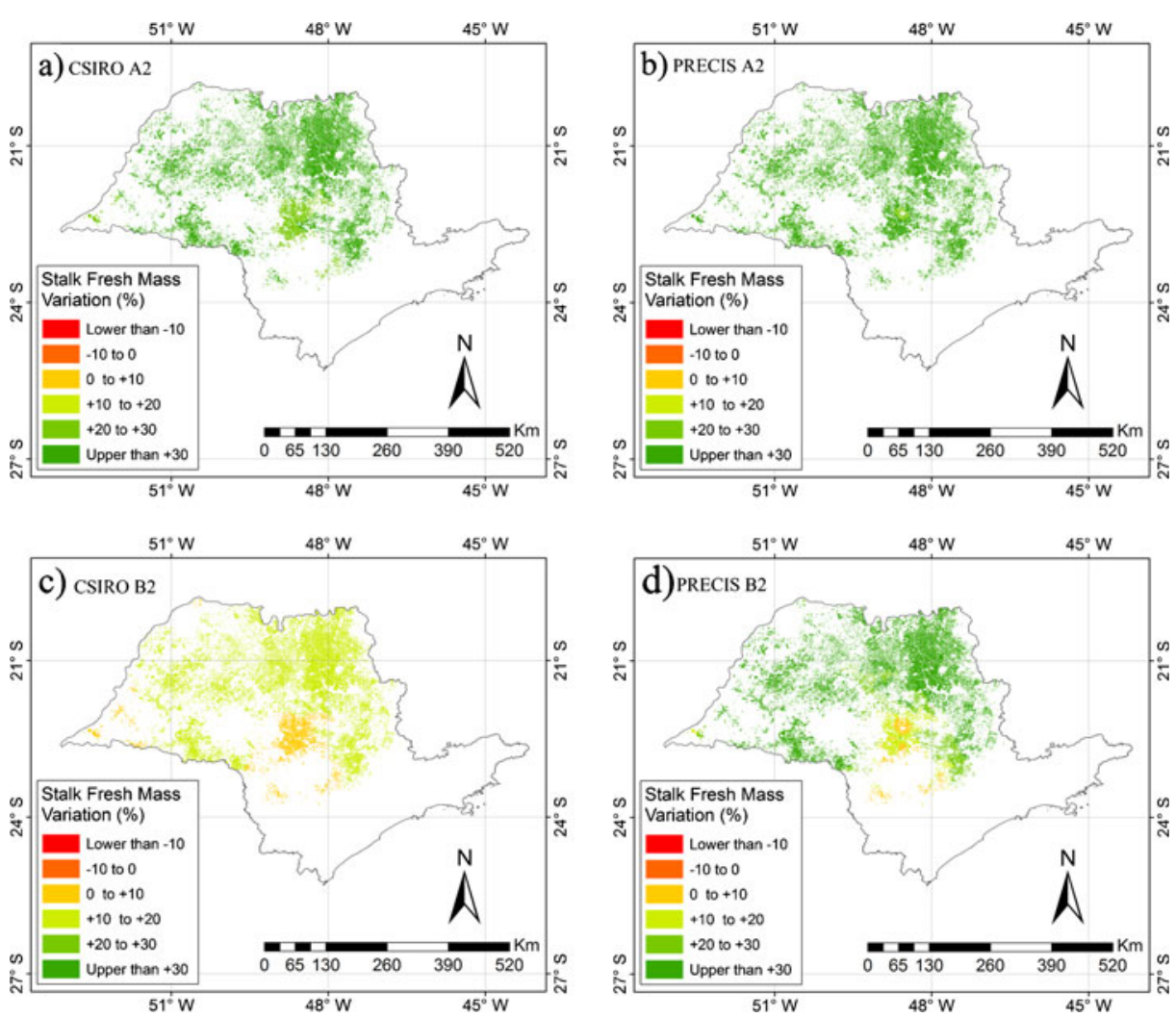

Fig. 3 Spatial distribution of the difference in stalk fresh mass simulated for the future projections and baseline growing area in 2011 of the State of São Paulo

(CSIRO B2) climate projection for sugarcane, respectively. The state SFM average in 2010 was 81 tha $^{-1}$ (IBGE 2011).

\subsubsection{Water use efficiency}

The decrease in stomatal conductance under elevated $\left[\mathrm{CO}_{2}\right]$ has been extensively reported as leading to a reduction in the transpiration rates (Long et al. 2004; Ainsworth and Rogers 2007). By assuming that these modifications in stomatal conductance and transpiration do not limit the photosynthesis rates under elevated $\left[\mathrm{CO}_{2}\right]$ (Nosberger et al. 2000), it seems reasonable to accept that water used efficiency (WUE - defined as dry biomass produced per unit of transpiration) would be increased under elevated $\left[\mathrm{CO}_{2}\right]$ conditions.

The WUE simulations resulted in increased WUE by $34 \%$ on average (Table 3 ). The simulations for PRECIS A2-early and medium cycles resulted in an increases of $58 \%$ for WUE. The larger WUE gains found in these simulations compared well with those observed by Souza et al. (2008) and Vu and Allen (2009) for well watered and fertilized potted plants, when WUE increased nearly $50 \%$.

The likely WUE gain under higher $\left[\mathrm{CO}_{2}\right]$ is also an important issue because the current concern about water supply in the State of São Paulo. Based on these future climate 
scenarios, irrigation would not become a requirement for sugarcane production in the State of São Paulo. Furthermore, as growers usually apply vinasse on sugarcane fields to relieve water stress during the winter and spring (Orlando et al. 1995), higher yield could be achieved using the same amount of vinasse in the future. In well-managed irrigation systems, this might represent an environmental benefit, since more vinasse may be used in sugarcane fields, reducing environmental problems associated with inadequate vinasse handling and storage, improving the soil quality and increasing the mitigation of $\mathrm{CO}_{2}$ emissions.

\subsection{Uncertainties and limitations}

Inevitably, the approach developed in this study which has linked climate scenarios and crop modeling has limitations. This study does not take into account the possibility of future change in daily rainfall distribution within the seasons, or changes in the frequency of extreme events such as droughts, heat waves or cloudiness, which could substantially change the results discussed here.

As we used multiple GCMs to help address uncertainty, the same approach could be extended by using multiple crop models. There has been a call for such an approach in studies on climate change impacts on agriculture (Rotter et al. 2011; Rosenzweig et al. 2012) to further address uncertainties.

DSSAT/CANEGRO crop model implementation embodies a number of simplifications such as ignoring the impacts of weeds, diseases, and insect pests on crop. Simulations also did not consider problems with soil conditions, e.g. salinity or acidity, fertility and management. The selection of three soils for the simulation and the cultivar calibration used were also sources of uncertainty. The model response to $\mathrm{CO}_{2}$ in the DSSAT version used seems too strong in terms of water savings.

\section{Concluding remarks}

Across all evaluated climate projections, simulations suggested the increase of SFM and the reduction of the yield variability for rainfed sugarcane in the State of São Paulo, Brazil. Simulations also suggested an increase for WUE rise, which is relevant because of the current concerns on water supply in southern Brazil. The WUE increase due to higher $\left[\mathrm{CO}_{2}\right]$ seems to be the main cause for the positive simulated yield response. Projected yields for 2050 ranged from 96 to $129 \mathrm{tha}^{-1}$ based on the current technological improvement rate.

Acknowledgements We are grateful to Dr. Mathew Jones (SASRI) for his help in the sensitivity analysis. We are also grateful to the anonymous reviewers for their valuable comments and suggestions. This research was partially supported by Brazilian Council for Scientific and Technological Development (CNPq) through the projects 478744/2008-0 and 0303417/2009-9 and Brazilian Agricultural Research Corporation (EMBRAPA) through the project 01.07.06.001.04.03.

Open Access This article is distributed under the terms of the Creative Commons Attribution License which permits any use, distribution, and reproduction in any medium, provided the original author(s) and the source are credited. 


\section{References}

Ainsworth EA, Rogers A (2007) The response of photosynthesis and stomatal conductance to rising [CO2]: mechanisms and environmental interactions. Plant Cell Environ 30(3):258-270

Allen LH, Jones P, Jones JW (1985) Rising atmospheric $\mathrm{CO}_{2}$ and evapotranspiration, Proc. Natl. Conf. on Advances in Evapotranspiration Chicago, IL, 16-17 December 1985, ASAE, St Joseph, MI, pp 13-27

Alvarez IA, Castro PRC, Nogueira MCS (2000a) Root growth of cane ratoon harvested green or burned. Sci Agric 57:653-659

Alvarez IA, Castro PRC, Nogueira MCS (2000b) Sugarcane root growth under burned and green harvest for two growing cycles. Sci Agric 57:653-659

Alves L, Marengo J (2010) Assessment of regional seasonal predictability using the PRECIS regional climate modeling system over South America. Theor Appl Climatol 100(3):337-350

Arnell NW (2004) Climate change and global water resources: SRES emissions and socio-economic scenarios. Glob Environ Chang 14(1):31-52

Barbieri JL, Alleoni LRF, Donzelli JL (1997) Agronomic and economic assessment of tillage systems for cane sugar. Braz J Soil Sci 21:89-98

Barros G (2009) Brazil: the challenges in becoming an agricultural superpower. In: Brazil as an economic superpower? - understanding Brazil's changing role in the global economy, Brookings, Washington, DC

Biggs JS et al (2012) Interactions between climate change and sugarcane management systems for improving water quality leaving farms in the Mackay Whitsunday region, Australia. Agriculture, Ecosyst Environ. doi:10.1016/j.agee.2011.11.005

Bristow KL, Campbell GS (1984) On the relationship between incoming solar radiation and daily maximum and minimum temperature. Agric For Meteorol 31(2):159-166

Cressman GP (1959) An operational objective analysis system. Mon Weather Rev 87:367-374

Drake BG, Gonzàlez-Meler MA, Long SP (1997) More efficient plants: a consequence of rising atmospheric CO2? Ann Rev Plant Physiol Plant Molecular Biol 48,:607-637

EMBRAPA (1999) Brazilian soil classification system. Embrapa Soils, Rio de Janeiro

Gleick PH (1986) Methods for evaluating the regional hydrologic impacts of global climatic changes. J Hydrol 88(1-2):97-116

Gordon HB, Rotstayn LD, McGregor JL, Dix MR, Kowalczyk EA, O’Farrell SP, Waterman LJ, Hirst CA, Wilson SG, Collier MA, Watterson IG, Elliott TI (2002) The CSIRO Mk3 Climate System Model [Electronic publication]. Technical report 60, CSIRO Atmospheric Research, Aspendale, Australia

Grantz DA, Meinzer FC (1990) Stomatal response to humidity in a sugarcane field: simultaneous porometric and micrometeorological measurements. Plant Cell Environ 13(1):27-37

Groissman P, Knight P, Easterling D, Karl T, Hegerl G, Razuvaek V (2005) Trends in intense precipitation in the climate record. J Clim 18:1326-1350

IBGE (2011) Municipal agricultural production. IBGE, Rio de Janeiro. Available at: http://www.sidra.ibge. gov.br/. Accessed 2 Nov 2011

Justino F, Setzer A, Bracegirdle TJ, Mendes D, Grimm A, Dechiche G, Schaefe CEGR (2011) Harmonic analysis of climatological temperature over Antarctica: present day and greenhouse warming perspectives. Int J Climatol 31(4):514-530

Knox JW, Rodríguez Díaz JA, Nixon DJ, Mkhwanazi M (2010) A preliminary assessment of climate change impacts on sugarcane in Swaziland. Agric Syst 103(2):63-72

Korndörfer GH, Primavesi O, Deuber R (1989) Growth and distribution of sugarcane root system in an Oxisol. Technical bulletin 47, Copersucar, Piracicaba, Brazil, pp 32-36

Leakey ADB, Uribelarrea M, Ainsworth EA, Naidu SL, Rogers A, Ort DR, Long SP (2006) Photosynthesis, productivity, and yield of maize are not affected by open-air elevation of $\mathrm{CO}_{2}$ concentration in the absence of drought. Plant Physiol 140(2):779

Long SP, Ainsworth EA, Rogers A, Ort DR (2004) Rising atmospheric carbon dioxide: plants FACE the future. Annu Rev Plant Biol 55:591-628

Maherali $\mathrm{H}$ et al (2002) Stomatal acclimation over a subambient to elevated $\mathrm{CO}_{2}$ gradient in a $\mathrm{C} 3 / \mathrm{C} 4$ grassland. Plant Cell Environ 25(4):557-566

Marengo JA, Jones R, Alves LM, Valverde MC (2009) Future change of temperature and precipitation extremes in South America as derived from the PRECIS regional climate modeling system. Int J Climatol 29(15):2241-2255. doi:10.1002/joc.1863

Marin FR, Jones JW, Royce F, Suguitani C, Donzelli JL, Pallone WJF, Nassif DSP (2011) Parameterization and evaluation of predictions of DSSAT/CANEGRO for Brazilian sugarcane. Agron J 103(2):304-314

Nassif DSP et al (2012) Parametrização e avaliação do modelo DSSAT/Canegro para variedades brasileiras de cana-de-açúcar. Pesq Agrop Brasileira 47(3):311-318 
Nosberger et al (2000) Grassland responses to climate change. In: Reddy KR, Hodges HF (eds) Climate change and global crop productivity. CABI, Wallingford, UK, pp 276-289

Oliveira JB, Camargo MN, Rossi M, Calderano Filho B (1999) Soil map of the State of São Paulo: complete legend (abstract in English). Instituto Agronômico, Campinas, Brazil

Orlando FJ, Bittencourt VC, Alves MC (1995) Vinasse application in a Brazilian sandy soil and nitrogen watertable pollution. Sociedade dos Técnicos Açucareiros do Brasil (STAB) 13(6):9-13

Ottman MJ, Kimball BA, Pinter PJ, Wall GW, Vanderlip RL, Leavitt SW, La Morte RL, Matthias AD, Brooks TJ (2001) Elevated $\mathrm{CO}_{2}$ increases sorghum biomass under drought conditions. New Phytol 150(2):261-273

Owensby CE, Ham JM, Knap AK, Bremer D, Auen LM (1997) Water vapor fluxes and their impact under elevated CO2 in a C4-tallgrass prairie. Glob Chang Biol 3:189-195

Rosenzweig C, Jones JW, Hatfield JL, Ruane AC, Boote KJ, Thorburn P, Antle J, Nelson G, Porter C, Janssen S, Asseng S, Winter JM, Greeley AP, Basso B, Ewert F (2012) The Agricultural Model Intercomparison and Improvement Project (AgMip). Agric For Meteorol (special issue)

Rotter RP et al (2011) Crop-climate models need an overhaul. Nat Clim Chang 1(4):175-177

Santos ACAS (2008) Assessment of genotypes of sugarcane for climate conditions of Aparecida do TaboadoMS (abstract in English). MSc Thesis, UNESP, Ilha Solteira, Brazil

Silva LC (2007) Growth analysis and nutrient accumulation for seven sugarcane cultivars in the Coruripe Region (abstract in English). MSc Thesis, UFAL, Maceió, Brazil

Singels A, Bezuidenhout CN (2002) A new method of simulating dry matter partitioning in the Canegro sugarcane model. Field Crop Res 78(2):151-164

Singels A, Jones M, van den Berg M (2008) DSSAT v4.5 Canegro sugarcane plant module: scientific documentation. SASRI, Mount Edgecombe, South Africa, $34 \mathrm{pp}$

Souza AP, Gaspar M, Silva EA, Ulian EC, Waclawosky AJ, Nishiyama MY JR, Santos RV, Teixeira MM, Souza GM, Buckeridge MS (2008) Elevated CO2 increases photosynthesis, biomass and productivity, and modifies gene expression in sugarcane. Plant Cell Environ 31(8):1116-1127

Tasso Jr LC (2007) Agrotechnology characterization of sugarcane cultivars(Saccharum spp.) in central-north region of State of Sao Paulo (abstract in English). PhD Thesis, UNESP, Jaboticabal, Brazil

Thornton PK, Jones PG, Alagarswamy G, Andresen J (2009) Spatial variation of crop yield response to climate change in East Africa. Glob Environ Chang 19(1):54-65

Tolbert NE, Zelitch I (1983) Carbon metabolism. In: Lemon ER (ed) $\mathrm{C}_{2}$ and plants: the response of plants to rising levels of carbon dioxide. Westview, Boulder, CO, pp 21-64

Trenberth KE, Jones PD, Ambenje P, Bojariu R, Easterling D, Klein Tank A, Parker D et al (2007) Observations: Surface and atmospheric climate change. Climate change 2007: the physical science basis. In: Qin D, Manning M, Chen Z, Marquis M, Averyt KB, Tignor M, Miller HL (eds) Contribution of Working Group I to the Fourth Assessment Report of the Intergovernmental Panel on Climate Change. Cambridge University Press, Cambridge

Venkataramana S, Gururaja Rao PN, Naidu KM (1986) The effects of water stress during the formative phase on stomatal resistance and leaf water potential and its relationship with yield in ten sugarcane varieties. Field Crop Res 13:345-353

Vu JCV, Allen LH Jr (2009) Stem juice production of the C4 sugarcane (Saccharum officinarum) is enhanced by growth at double-ambient $\mathrm{CO}_{2}$ and high temperature. J Plant Physiol 166(11):1141-1151

Vu JCV, Allen LH, Gesch RW (2006) Up-regulation of photosynthesis and sucrose metabolism enzymes in young expanding leaves of sugarcane under elevated growth CO2. Plant Sci 171(1):123-131

Ziska LH, Bunce JA (1997) Influence of increasing carbon dioxide concentration on the photosynthetic and growth stimulation of selected C 4 crops and weeds. Photosyn Res 54(3):199-208 